\title{
Frontières
}

\section{Le funambule et la trapéziste}

Volume 20, numéro 2, printemps 2008

Les musiques et la mort

URI : https://id.erudit.org/iderudit/018358ar

DOI : https://doi.org/10.7202/018358ar

Aller au sommaire du numéro

Éditeur(s)

Université du Québec à Montréal

ISSN

1180-3479 (imprimé)

1916-0976 (numérique)

Découvrir la revue

Citer ce document

(2008). Le funambule et la trapéziste. Frontières, 20(2), 109-109.

https://doi.org/10.7202/018358ar

Ce document est protégé par la loi sur le droit d'auteur. L'utilisation des services d'Érudit (y compris la reproduction) est assujettie à sa politique d'utilisation que vous pouvez consulter en ligne.

https://apropos.erudit.org/fr/usagers/politique-dutilisation/
Cet article est diffusé et préservé par Érudit.

Érudit est un consortium interuniversitaire sans but lucratif composé de l’Université de Montréal, l'Université Laval et l'Université du Québec à Montréal. Il a pour mission la promotion et la valorisation de la recherche. https://www.erudit.org/fr/ 


\section{SURLE $\overline{\text { Le funambule et la }}$ a 드...... $\infty$ interprétée par Milly. \\ Durée: $4 \min 11 \mathrm{~s}$}

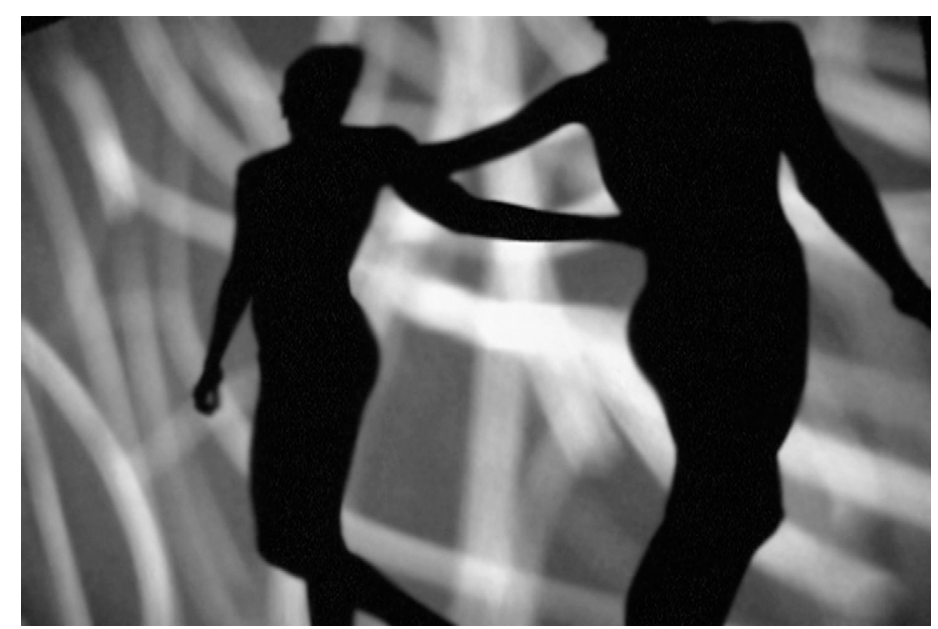

Venez saluer l'équilifriste

Qui suspend le temps sur la piste

C'est pour ce soir, le grand départ

Un pas en avant malhabile Et le funambule perd le fil

Ébloui par les projecteurs

Il défic l'apesanteur

La vie vaut-elle d'être vécue

Quand un amour n'a plus d'issue

Pourquoi se raccrocher au fil

Quand les deux amants se défilent

Venez saluer l'équilifriste

Qui suspend le temps sur la piste

C'est pour ce soir, le grand départ

Elle sent sa gorge qui se serre

Elle sait ce qu'il lui reste à faire

Alors elle attrape en silence

Le grand trapezze et se balance

Dans une lumineuse pantomime

Le funambule plonge dans l'abîme

La trapéziste dans un élan

S'envole et rejoint son amant 